\title{
“CIDADE VIGIADA", “CIDADE CIVILIZADA": Impressões sobre a difícil convivência entre o progresso e a pobreza no Recife Imperial (1830 - 1850)
}

\author{
Grasiela Florêncio de Morais*
}

\begin{abstract}
RESUMO: Esse trabalho tem como cenário o Recife da primeira metade do século XIX (1830-1850), uma cidade que se pretendia moderna e civilizada. Para isso, contou com as ações empreendidas pelas autoridades citadinas para propor e impor projetos de melhoramentos materiais e morais à capital da província. Ao lado do progresso que se queria imprimir no Recife havia a pobreza que se fazia ostensiva e se espraiava pelos redutos da cidade. Os sujeitos que viviam na pobreza, por sua vez, além de sofrerem com as restrições de sua condição ainda estavam submetidos à vigilância cotidiana das autoridades, portanto o diálogo entre esses atores era tenso. Para discutirmos sobre a temática, nos debruçamos sobre os manuscritos da Câmara Municipal do Recife e das Prefeituras de Comarca, os periódicos Diário Novo e Diário de Pernambuco e os impressos dos Relatórios dos Presidentes de Província.
\end{abstract}

PALAVRAS-CHAVE: Recife; Progresso; Pobreza.

\section{"Surveyed city", "civilized city": Impressions about the hard living between progress and poverty at Imperial Recife $(1830$ - 1850)}

\begin{abstract}
This work takes place in Recife, during its 19th century's first half (1830-1850), as a city which was intended to be modern and civilized. In order to become that, local authorities of Recife had proposed and imposed projects in the sense of improve both structural and moral aspects. Beside the progress which wanted to be done on Recife, there was poverty that was made ostensive and got irradiated through the town's stronghold. The ones who lived in poverty, in turn, beyond suffering with the restrictions of their condition were submitted to authorities' daily surveillance; therefore dialogue between these parts was tense. For discuss about this subject, we gave our attention to manuscripts of Recife Municipal Council and City Hall, the periodics Diário Novo and Diário de Pernambuco and Reports of the Provincial Presidents.
\end{abstract}

KEYWORDS: Recife; Progress; Poverty.

\section{"Ciudad vigilada", "Ciudad civilizada": Impresiones de la difícil convivencia entre el progreso y la pobreza en Recife Imperial (1830 - 1850)}

RESUMEN: Este trabajo se centra en la ciudad de Recife de la primera mitad del siglo XIX (1830-1850), una época en que la ciudad parecía destinada a ser,a la vez, moderna y civilizada. Para tanto, fueron fundamentales las acciones que las autoridades propusieron y, también, impusieron con relación a proyectos de mejoras materiales y morales en la capital provincial. El progreso que se proponía imprimir a Recife dividía espacio con la gran pobreza que se extendía por los alrededores de la ciudad. Los pobres, a su vez, además de sufrir las limitaciones de su condición, estaban también sometidos a la vigilancia diaria de las autoridades. Por lo tanto, el diálogo entre estos actores fue tenso. Para discutir sobre el tema, consultamos los manuscritos del Consejo de la ciudad de Recife y de las "prefeituras de comarca", los periódicos "Diário Novo" y "Diário de Pernambuco" y también los documentos de los presidentes de la Provincia.

PALABRAS-CLAVE: Recife; Progreso; Pobreza.

\footnotetext{
* Mestre em História Social da Cultura Regional pela Universidade Federal Rural de Pernambuco e doutoranda em História pela Universidade Federal de Pernambuco. E-mail: moraisgrasiela@yahoo.com.br
} 
Dos outeiros de Olinda, avançando uma légua em direção à planície, descia um istmo, protegido dos arroubos do mar pela extensa linha de arrecifes. Na ponta desse istmo [...] reuniam-se as condições excepcionais que fizeram do lugar o principal ancoradouro da colônia ${ }^{1}$.

O "ancoradouro da colônia" assegurado pelos "arrecifes", descrito por Raimundo Arrais, trata-se do Recife, que de pequeno e humilde povoado de pescadores no século XVII, transformar-se-á em "cidade-capital"2 da província de Pernambuco já na primeira metade do século XIX. Através do seu porto - ponto de escoamento de produtos diversos, de pessoas e de ideias que comunicavam sonhos e interesses de diferentes lugares, em particular, após o ano de 1808, com a abertura dos portos brasileiros às "nações amigas" - adquiriu importância econômica e política no cenário local e nacional. Assim, superou a antiga capital pernambucana (Olinda) em prestígio e poder.

Como resultado deste processo, o Recife alargou o tracejado dos seus espaços sociais, seguindo os limites impostos pelo curso das águas do rio Capibaribe, por meio de aterramentos contínuos em seus bairros centrais. Esta expansão acabou por se refletir numa certa especialização de seus bairros. Assim a "Veneza Americana" (imagem que se consolidou do Recife e que se exibiu com maior longevidade) se tornou um centro urbano expressivo figurando entre as três principais capitais brasileiras, atrás apenas das cidades do Rio de Janeiro - onde se situava a Corte Imperial - e Salvador, na Bahia ${ }^{3}$.

O seu complexo urbano se dividia nos seguintes bairros centrais: o de São Frei Pedro Gonçalves (hoje, conhecido como o Recife Antigo); o de Santo Antônio; o de São José e, por último, o da Boa Vista que, comunicavam-se por meio de três pontes projetadas sobre as grandes extensões de água que cortavam a cidade de norte a sul, leste a oeste ${ }^{4}$. Era através dessas águas que o progresso chegava a Pernambuco. Em meio às canoas que trafegavam diariamente pelos seus rios, transportando não só pessoas, mas as ferramentas fundamentais à edificação e ao desenvolvimento da cidade.

Contudo, o espaço urbano da cidade se confundia com a sua paisagem rural. Para Kátia Mattoso, “[...] a cidade e o campo são, no Brasil, estreitamente inter-relacionados. [...] As cidades são pomares, hortas, campos urbanizados", Portanto, havia apenas uma tênue separação entre a cidade e o campo. Mas, para se enquadrar no projeto de civilização ao qual se pretendia, a fim de compor o Estado Moderno, era necessário desvanecer a imagem "rurbana" da cidade. Pois, em virtude de sua condição e dos valores atribuídos à cidade na época, o Recife deveria racionalizar os seus espaços, ou seja, vencer a sua natureza por meio 
de técnicas que promoveriam tanto o seu embelezamento quanto o seu melhoramento material.

Assim, procurava-se acabar com os hábitos e os costumes do passado colonial visto simbolizarem o atraso. Logo, "ser independente era tornar-se igual, civilizar-se era virar branco e europeu" e, por que não citadino?" Afinal de contas, o lugar da "civilização" e do "progresso" era a cidade; onde a ciência e a razão se responsabilizariam pela sua boa condução, administrando a reconstituição do seu passado e projetando-a no futuro, a fim de superar possíveis equívocos que viessem representar empecilhos à construção da "nova ordem" que se queria impor à sociedade. Por este motivo, as principais cidades brasileiras se transformaram em centros (políticos, econômicos, culturais e sociais) e passaram a concentrar não apenas bens, serviços, investimentos estrangeiros, órgãos administrativos, mas também um numeroso contingente populacional atraído pelo enaltecimento do modo de vida urbano. Esta valorização promoveu uma constante movimentação de ideias e de indivíduos nos espaços da cidade que passavam a ser pensados e redefinidos sob a ótica das elites dirigentes.

José Carlos Barreiro, ao analisar os testemunhos dos viajantes estrangeiros que pisaram em terras brasileiras ao longo do século XIX, aponta que a problemática do espaço urbano no Brasil esteve orientada pela questão urbana europeia e também pela ideia sanitária, pois, "a vigilância constituiria como instrumento decisivo de dominação burguesa" 8 . Portanto, modernizar-se (material e moralmente) era sinônimo de ordenamento que deveria estar em consonância com os padrões disciplinares - tais como, as leis, as posturas, os projetos higienistas e os aparatos policiais.

Afinal de contas, era preciso tornar a cidade, além de bela, um espaço são e seguro a fim de se coibir os modos de fazer e de viver de sujeitos descritos como "bárbaros" ou "selvagens", opostos simbólicos dos termos "civilizado" e "polido". Contudo, a maior parcela da população não atendia às pretensões de civilidade, as suas práticas eram comumente retratadas como inadequadas e estavam sujeitas à constante vigilância do projeto modernizador. Robert Pechman resume bem esta questão: “[...] da população, cuidaria a polícia [...]; da cidade, cuidaria o urbanismo"9.

A cidade enquanto palco das práticas modernizadoras proporcionou o encantamento de muitos sujeitos. Mas, ao mesmo passo, também alimentou um sentimento reverso, o de desilusão. Pois, não podemos acreditar que todos os sujeitos estavam embebidos com as idéias do "projeto normatizador". Muito provavelmente, uma boa parcela da população nem sequer o compreendia; assim como os seus efeitos "modernizantes" poderiam adquirir 
sentidos diversos ao pretendido, visto estarem sujeitos à constante manipulação de praticantes que não o fabricavam, mas que intervinham segundo seus interesses e regras próprias.

O cenário do Recife para o viajante inglês Henry Koster - o qual viveu nas primeiras décadas dos oitocentos - havia sido incorporado pelo "espírito de renovação" que parecia ter tomado conta da capital e das pessoas. Era, segundo ele, a "época dos melhoramentos" que vinha proporcionando outros ares à cidade, transformada em um canteiro de obras. "Várias casas tinham sido reparadas e as rótulas ${ }^{10}$, sombrias e pesadas, foram substituídas pelas janelas, com vidros e balcões de ferro"," "trabalho das fundições e oficinas de ferreiro locais" "12. Assim esta intensa valorização da capital possivelmente tornou propício o aumento de preços do metro quadrado dentro dos seus limites e nos seus arrabaldes. Segundo o inglês, "as terras próximas ao Recife subiam de preço" e o "comércio de tijolos estava convenientemente lucrativo"13.

Este desenvolvimento ou "melhoramento" foi acompanhado pelo crescimento populacional na cidade o que acarretou uma grande demanda por terras em seus limites físicoespaciais. Mas as dificuldades eram muitas, pois, primeiramente, a falta de espaços suficientes e adequados para a ocupação era uma realidade e também se deve levar em consideração que viver nasede políticae administrativa da provínciaera deveras dispendioso. Para o Recife que "aumentava dia a dia de importância e opulência"14 isto trazia muitas implicações, tais como, a constante ocupação e valorização de seus arrabaldes, em particular as áreas conhecidas como Monteiro, Poço da Panela e Madalena. Ademais, este efeito incidia fortemente no problema da habitação que atingia, sobretudo, os sujeitos mais pobres suprimidos pelo "progresso" na cidade.

Para a historiografia, a "época dos melhoramentos" no Recife oitocentista se deu décadas após a chegada de Henry Koster a Pernambuco. Foi durante o governo do presidente Francisco do Rego Barros (1837 a 1844), Barão e depois Conde da Boa Vista. De fato, em seu governo a cidade sofreu uma grande modificação na sua paisagem urbana. Conforme Orlando Parahym,

[...] ele deu a Pernambuco arrojado impulso progressista em todos os setores da atividade pública: florescimento comercial e industrial, renovação urbanística, instrução pública, aterros de pântanos e alagados, manutenção de pontes e estradas, construção do palácio do governo, [...] limpeza da cidade, estímulo a vida social $[\ldots]^{15}$. Grifos nossos.

Ainda que a descrição acima enalteça sobremaneira a figura política de Francisco do Rego Barros, não podemos contestar as suas contribuições político-administrativas na 
província, em particular, no que se referem à "renovação urbanística", as suas tentativas em promover a "limpeza na cidade" e ao estímulo à vida social - principalmente para os grupos mais abastados da sociedade pernambucana. Ao mesmo passo se faz necessário refletir acerca desse "arrojado impulso progressista". Quem seriam os personagens mais interessados em tal ação? Quais sujeitos seriam beneficiados por esta política?

Ao se portar diante da Assembleia Legislativa Provincial de Pernambuco, para apresentar o seu primeiro relatório presidencial com apontamentos referentes às ações ocorridas durante o ano de 1837, Rego Barros já descreve as suas pretensões iniciais:

Cumprindo o dever que me impõe a lei [...] venho expor-vos o estado desta província, propor-vos aqueles melhoramentos, (...) que me tem parecido ela necessitar e pedir-vos as providências Legislativas, afim de que chegue aquele grau de prosperidade, a que ela tem direito, e ao qual certo atingirá, se os nossos esforços forem convergindo, como até agora para torná-la rica, moral, ilustrada e Cristã $[\ldots]^{16}$. Grifos nossos.

Assim, propor "melhoramentos" em Pernambuco e, em particular, no Recife,foi uma das suas maiores intenções políticas. No entanto, ainda que gozasse de certa autonomia política para administrar, os seus esforços também dependiam da vontade das autoridades legislativas e, por esta razão, em seu discurso procura convencê-los de que apenas um esforço comum poderia alavancar "aquele grau de prosperidade" tão almejado e de que tanto necessitava a província para se tornar “rica, moral, ilustrada e Cristã".Ou seja, os melhoramentos deveriam atender tanto os aspectos materiais, mas, sobretudo, os morais.

Para tornar mais rica a província, era preciso criar as ferramentas necessárias ao seu crescimento, ou melhor, ao desenvolvimento do setor agrário, carro-chefe da economia local, com a produção de gêneros como a cana-de-açúcar e o algodão. Na mesma medida, também alavancar as atividades comerciais. Portanto, as autoridades políticas eram as mais interessadas, pois a maior parte deste universo era composta por representantes da elite agroexportadora. Estes eram os sujeitos que guiavam a administração da província e definiam os limites das ações públicas. Dessa forma, Rego Barros conseguiu governar a província por um relativo tempo, o que propiciou à mesma um "impulso progressista", promovendo a "intensa" urbanização da cidade, através da realização de inúmeras obras públicas, tudo com o objetivo de tornar a "realidade" da capital próxima a das cidades europeias da época. Assim almejava erguer uma sociedade que possuísse as marcas da civilização.

Contudo, não podemos reduzi-lo apenas à sua atuação política no campo da gestão de obras públicas empreendidas no Recife. Assim como também não devemos achar que ele foi 
o único governante a se preocupar com estas questões, pois existiram outros que procuraram dar aparentes impulsos modernizantes à cidade de acordo com as concepções de suas épocas. Fato é que para a historiografia, Rego Barros tem uma forte marca pessoal, a de governante empreendedor. Neste contexto, ao consolidar esta imagem, muitas vezes ficam implícitas as tensões e os problemas que se teciam durante a vigência de sua administração. Entendemos que por trás das grandes obras edificadas sob a influência da arquitetura europeia; por entre as casas enumeradas; por meio das ruas que passaram a contar com os tímidos lampejos de iluminação e calçamento; assim como, por trás das tentativas de tornar salubre a capital se movimentava uma sociedade que se caracterizava pela desigualdade e pela incompatibilidade de interesses e necessidades ${ }^{17}$.

Logo, a necessidade de modernização parecia não dar conta de determinados problemas que faziam parte do cotidiano das cidades, tais como a fome, a miséria, o desemprego e a violência. As autoridades tentavam mesmo que sob o critério da aparência e da ação paliativa melhorar determinados serviços (como o abastecimento de água com a implantação de chafarizes na cidade; o reparo das pontes e a implantação da iluminação em dadas ruas, entre outras), tanto com o intuito de auxiliar o cotidiano e a sobrevivência de uma parte da população a fim de promover o bem-estar entre estes, quanto com a finalidade de melhorar os meios de vigilância sobre a população visto que as suas práticas poderiam surtir o efeito contrário aos preceitos da "nova ordem" que se aspirava. Logo, para se tornar em uma "cidade civilizada" era preciso, antes de tudo, valer-se de ferramentas apropriadas para ser também uma "cidade vigiada".

Ao buscar ares civilizados para o Recife, as elites governantes pretendiam remodelar os seus espaços geográficos, os modos e as modas de seus habitantes por meio de vestes à europeia. Mas ainda perduraram as suas antigas práticas e contornos sociais que tanto caracterizavam o cotidiano turbulento das suas ruas, becos e travessas labirínticas. Lugares marcados pelo trabalho, e pelos cânticos de escravos(as), libertos(as) e dos sujeitos pobres livres que conviviam com uma variada gama de aromas de frutas tropicais e dos quitutes presentes nos tabuleiros que circulavam diariamente pelos redutos pouco asseados da "cidade negra" ${ }^{18}$. Entretanto, além de lugar de moradia e de trabalho destes e de muitos outros indivíduos, a cidade era também o espaço da pobreza e da miséria social. Em seus limites se encontrava uma parcela considerável da população que procurava sobreviver em meio a esta dura realidade. De acordo com João José Reis, "havia muita pobreza, e a escassa riqueza que havia estava concentrada nas mãos de poucos" ${ }^{\prime 19}$. 
Conforme já apontamos, os símbolos do progresso que adornavam o quadro das cidades brasileiras se apresentavam em meio a muitas contradições e turbulências de toda a ordem. Já em fins do século XVIII, Luís dos Santos Vilhena descreve, em algumas de suas cartas, que "o Brasil era a morada da pobreza" e o "teatro dos vícios" 20 . Então, a "época dos melhoramentos" não seria diferente, haja vista continuar edificada em bases muito delicadas que "arrastava consigo um grande número de indivíduos, constantemente afetados pelas flutuações e incertezas do mercado internacional" e nacional, e, por esta razão, tornava bastante dificultoso aos sujeitos "desprovidos de cabedal" 21 o acesso às fontes geradoras de riqueza. Era nesse espaço que a pobreza dava os seus suspiros e se multiplicava, uma vez que "a sua existência e permanência ocorre como um subproduto da sociedade que a consente, que dela vive, envolvendo, portanto uma dada interdependência",22.

Não pretendemos aqui buscar as suas causas por considerarmos mais relevantes os seus efeitos e as suas implicações sociais. Portanto, a pobreza se fazia ostensiva nas cidades oitocentistas e era permeada tanto pelo universo da escravidão quanto pelo da concentração de bens e terras nas mãos de poucos, ampliando os horizontes da marginalização de boa parte da população. Ao tratarmos desta temática, precisamos compreendê-la dentro do contexto do século XIX, notadamente, entre as décadas de 1830 a 1850. Como o Estado se relacionava com a pobreza? Assim como, analisar como homens, mulheres e crianças; livres e escravos; brancos e mestiços procuraram conviver com os seus percalços.

No Brasil, a pobreza foi retratada desde os tempos da colonização por diversas autoridades - políticas, religiosas, entre outras - receosas e preocupadas com os rumos da sociedade. Entre estas, podemos apontar o relevante papel desempenhado pelos membros eclesiásticos no tratamento da pobreza; sob o manto Cristão - educador e moralizador procuraram denunciar os seus males à sociedade e, na mesma medida, enfatizar a importância da religião que visava cultivar os valores morais e pregar o ordenamento do indivíduo e da própria coletividade. Além da ação da Igreja, nos oitocentos o país também contou com o emergente discurso médico que ganhava impulso com o passar das décadas ${ }^{23}$. Assim como a Igreja, a medicina também prometia "curar", "moralizar" e "regenerar" os indivíduos, mas os meios seriam distintos, visto o seu desempenho se dar com base nas chamadas "verdades científicas", ou seja, as respostas seriam proporcionadas pelo poder da ciência que prometia garantir e defender a "boa moral" e os "bons costumes".

Para isso, os aparatos médicos caminharam a fim de ampliar os seus leques de atuação no âmbito social, cujas metas seriam: "ultrapassar uma perspectiva de intervenção limitada à 
vida individual", ou seja, nesse sentido, não pretendiam apenas permanecer restrito ao domínio da casa grande e dos sobrados, pois, também intencionavam atuar em "diversos estratos do tecido social" ${ }^{24}$. Contudo, no plano das ações, isso não se deu de forma repentina, pois, foi gradualmente que os "sujeitos da racionalidade" foram conseguindo conquistar territórios e obter legitimação social. Conforme José Gondra,

[...] além de se preocuparem com as questões específicas da medicina (estudos de patologias, de técnicas de intervenção clínica e cirúrgica, farmacologia e obstetrícia, dentre outros), também se mostravam preocupados com outras questões e objetos, tais como o problema da moralização, dos cemitérios, do aleitamento, do casamento, das práticas de infanticídio, puberdade, prostituição, higiene militar, pobreza, alimentação, entre outros $[\ldots]^{25}$. Grifos nossos.

Nesse quadro, podemos perceber que a "pobreza" se configurava como uma das muitas inquietações para as autoridades médicas que pretendiam refreá-la por meio de medidas e intervenções no espaço público, a fim de consumarem o desejo de civilizar a nação pelo viés da ciência. Não só isso, porém também refrear os passos e as condutas dos sujeitos pobres. Foi o pensamento europeu, sobretudo o francês, o norteador das práticas médicas no Brasil ao longo do século XIX, onde a pobreza era tida como "sintoma de um mau funcionamento patológico da sociedade, assim fonte do crime e do perigo". O médico francês Louis-René Villermé, em meados da década de 1840, descreveu-a como um dos males a ser regenerado, pois era fruto do "desregramento moral" e afetava, sobretudo, "as famílias de conduta reprovável" ${ }^{\prime 26}$. Portanto, a pobreza estava associada à degeneração dos indivíduos e ao "mundo do crime", todos referentes ao "problema da moralização" social.

Para além dessas percepções e sensibilidades, sobre a pobreza no período em tela, segundo José Roberto Lapa entendemos por,

[...] uma situação de carência (privação), de impossibilidade de atendimento de necessidades materiais básicas à sobrevivência física e reprodução, dentro naturalmente do quadro de valores e disponibilidades de uma determinada sociedade e conjuntura. O que significa dizer, em outras palavras, que se têm em conta expectativas, desejos e costumes [...] que pesam nesse condicionamento ${ }^{27}$.

Uma carência que correspondia ao não atendimento de necessidades tidas como mínimas e essenciais à sobrevivência dos indivíduos, tais como a alimentação, a habitação, o vestuário, a mobilidade, entre outras. Através dos indícios destas privações encontramos, muito provavelmente, os sujeitos pobres (personagens centrais da nossa história, sobretudo as mulheres) que compunham um quadro numeroso nas cidades e viviam em meio a muitas 
dificuldades. Mas, para muitos, as suas lutas eram incansáveis na tentativa de mudarem a sorte de suas vidas e destinos.

Para Antônio de Morais Silva, autor de um dicionário da época, o termo pobre significava: "o que não é rico, a quem falta o necessário para a vida", sujeito "que tem poucas posses, [...] o que pede pelas portas, o pedinte [...]"28. Em Fonseca o termo também se traduzia em: "aquele que vive com poucas posses, que não é rico"; além disso, era considerado como "infeliz, coitado e de pouco valor" ${ }^{29}$. Estes dois trechos resumem de maneira simbólica a representação que o pobre tem para a sociedade oitocentista, ou seja, ser pobre é viver sob privações e contar com um número reduzido de posses ou até mesmo de nenhuma e, nessa circunstância, ser impelido a "pedir pelas portas" - tais como, faziam os “pedintes", "mendigos”, entre outros - e estar entregue à própria sorte.

O pobre foi construído discursivamente como um "infeliz" e indivíduo de "pouco valor" e importância, por isso, um "coitado". Portanto, de acordo com as definições dos verbetes citados, aos quais trazem em seu bojo valores de uma dada época, podemos refletir que para os oitocentos não havia clareza na distinção entre os indivíduos que configuravam o mundo da pobreza, ou melhor, entre aqueles que viviam miseravelmente e os que viviam em situação um pouco mais remediada - de outro modo, consideramos aqueles que possuíam pequenas posses e até mesmo contavam com um número reduzido de escravos. Nesse conjunto, poderíamos encontrar os pequenos artesãos, aprendizes, pequenos proprietários e jornaleiros. ${ }^{30}$ Seguindo este percurso, reparamos o quanto se dá importância ao material (bens, posses). Ou seja, aos indivíduos só seria crucial ter bens? Mas, para as sociedades burguesas este enaltecimento tinha a sua relevância e finalidade, pois serviria como parâmetro para estabelecer, definir, separar e distinguir os grupos sociais.

Quanto ao fato do sujeito pobre (de condição jurídica: livre, liberta ou escrava) ter escravos, ainda que em número consideravelmente reduzido, mencionou a este respeito João José Reis, ao estudar a sociedade baiana no período em tela,

[...] os escravos não eram propriedade apenas de grandes senhores de engenho e negociantes urbanos (aqueles que poderíamos chamar estritamente de "classe dominante"), pois seus donos estavam espalhados por diversas classes e setores sociais. [...] possuir escravos não era coisa apenas de gente rica. Só os muito pobres não tinham escravo algum $[\ldots]^{\prime 31}$. Grifos nossos.

Esse aspecto nos levou as impressões do viajante francês Tollenare que em suas notas dominicais, ao registrar imagens do cotidiano da cidade e de seus arrabaldes, assim descreveu: 
Os cultivadores brasileiros (lavradores) perto da cidade possuem algumas vezes um ou dois escravos, vi alguns que tinham feito armar a rede sob as árvores, nela repousavam negligentemente; suas mulheres estavam deitadas por terra sobre esteiras: a dez passos deles uma negra arrancava lentamente alguns talos de mato. Parecia que a preguiça descendo com o calor havia deixado cair sobre todos eles os seus vapores entorpecentes $[\ldots]^{32}$. Grifos nossos.

Não pretendemos aqui analisar a relação escravo-senhor, mas considerar que os indivíduos pobres poderiam ter, entre as suas "poucas posses", escravos(as) que garantiam e auxiliavam os seus sustento e o de suas famílias, assim como o de agregados; ou seja, pobres mas não despossuídos. Além disso, ter cativos era significativo por ser um imperativo de poder e status. Logo, tal fato poderia representar certa "distinção" e "prestígio" dentro do universo da pobreza. Contudo, para Hebe Mattos, ter a posse de escravos ou até mesmo de terras não era o único meio decisivo para viver em "condições remediadas", pois, além desses, "a diversidade sócio profissional urbana ou artesanal eram cruciais para engendrar a subsistência" no espaço urbano ${ }^{33}$.

Isso nos leva a refletir acerca dos valores atribuídos ao trabalho, bem como a sua especialização na época. O próprio relato do Tollenare, além de tratar dos "senhores de poucos escravos", nos oferece ao menos um indício acerca da questão. Ao abordar o modus vivendi dos "cultivadores brasileiros", das suas mulheres e de uma negra (provavelmente cativa) com relação ao trabalho, mostra-os domados pelos efeitos dos "vapores entorpecentes" da preguiça. A indolência tão comumente apontada tanto por estrangeiros quanto por aqueles nascidos no Brasil era tida como costume dos habitantes, que pareciam ter ojeriza ao trabalho, sobretudo, o trabalho manual. Ademais, por esta razão, o conceito "preguiça" facilmente se confundia com os seguintes termos: "vadio", "remisso", "negligente", entre outros. Na maior parte das vezes estavam atrelados aos sujeitos oriundos das classes populares.

No dia 3 de fevereiro de 1843, o padre Miguel do Sacramento Lopes Gama, cronista da época, em seu periódico O Carapuceiro resumiu da seguinte forma,

Os forros pobres do nosso país, já pela sua má educação, já pela mesma fertilidade da terra, que espontaneamente produz com que sustentar a vida, são ordinariamente vadios e remissos, mas há além disto o grande obstáculo dos escravos, [...] a toda hora encontram naqueles infelizes outros tantos termos de comparação, e daqui $\underline{0}$ mais pequeno trabalho os revolta e preferem uma vida quase nômade à sujeição de trabalhadores jornaleiros [...]. Que moralidade pode haver entre nós, que respeito à lei, se nos mais elevados somos tão mal educados e tão cheios de vícios? [...] $]^{34}$. Grifos nossos.

O descaso com relação ao trabalho seria um dos muitos "vícios" que encobria a nação. Segundo Marco Pamplona, para a elite brasileira, o trabalho não conferia dignidade e não 
garantia status social; ainda estava relacionado apenas aos escravos, mas também às chamadas "classes baixas" em geral ${ }^{35}$. Esta noção promovia reflexos entre os pobres livres, libertos e até mesmo escravos que também reproduziam estes valores, ou seja, não se resumia a elite brasileira. Nesse âmbito, segundo Lopes Gama, havia os que preferiam viver como nômades (sujeitos a muitas dificuldades) a ter que se submeter a trabalhos jornaleiros, por não querer ser confundidos ou tratados como escravos, uma desonra. Para o referido padre, se o Brasil quisesse se tornar "próspero e bem morigerado" era necessário ter "uma educação bem dirigida para infundir em nossa mocidade o amor do trabalho", assim como dispor de "boas leis policiais para espancar o vadiismo" 36 .

Esse era o palco cotidiano dos nossos personagens (homens e mulheres pobres, livres e escravos) que viviam em trânsito nos espaços da cidade, lugar onde procuravam superar e sobreviver aos constantes obstáculos (referimo-nos, em particular, ao problema da alimentação, da moradia e da violência) ao qual estavam submetidos. Para tanto, ao buscarmos compreender os significados da pobreza para a sociedade recifense nos oitocentos, procuramos relacioná-la ao processo de modernização urbana empreendida na época que tinha como finalidade promover: a "ordem", o "progresso" e o "bem-estar" para os cidadãos.

Apesar da difícil convivência entre a pobreza e o progresso na cidade, não podemos esquecer que esse foi o momento de intenso desenvolvimento econômico e social para a capital da província; no primeiro plano, o Recife se firmou como centro econômico regional e lucrava com os surtos produtivos da indústria agroexportadora de açúcar e de algodão. Silvio Zancheti afirma que "o comércio recifense seguiu as esteiras dos desbravadores pernambucanos do sertão, interligando as diversas áreas produtoras do interior nordestino ao núcleo urbano" ${ }^{37}$. Esse processo, por sua vez, foi acompanhado pelo crescimento acelerado da população nos bairros centrais (Recife, Santo Antônio, Boa Vista e, por último, São José) durante a primeira metade do século XIX.

Para isso, baseamo-nos numa contagem realizada em 1828, por Figueira de Mello, o Recife possuía um total de 25.678 habitantes, distribuídos pelos três bairros centrais - Recife, Santo Antônio e Boa Vista. Desse total, 17.743 eram indivíduos livres - os libertos (exescravos) também estavam incluídos nessa mesma categoria - e os 7.935 restantes eram escravos. Anos depois, em 1856 foi realizada outra contagem que indicou um total de 40.977 habitantes na capital, significando um aumento de quase $60 \%$ do total da população na cidade. Esses dados nos servem como referência, mesmo sabendo-se que estas informações não traduzem a "realidade" 38 
Acerca das possíveis causas desse aumento populacional consideramos que não se deviam apenas ao seu crescimento natural, mas também ao constante fluxo migratório dos arrabaldes e de áreas mais distantes, sobretudo o sertão. Por exemplo, em tempos de catástrofes naturais, em especial, referimo-nos aos ciclos de secas, a situação se agravava sobremaneira e impelia um contingente numeroso de flagelados buscarem socorro no Recife, mas combalidos pelo cansaço e pela fome, esses iriam apenas somar na pobreza com o grande número de mendigos que a cidade já possuía ${ }^{39}$. Sem moradia ou recursos financeiros suficientes para garantir a subsistência, uma parcela significativa de migrantes se espalhava pelas ruas da cidade a procura de abrigo. No entanto, as dificuldades enfrentadas por esses indivíduos eram copiosas, tendo em vista que ficavam à prova da precária condição de sobrevivência, bem como estavam mais susceptíveis aos riscos da violência urbana.

Além do crescimento econômico e do "inchaço" populacional, ocorreram momentos de intensos burburinhos, causados por inúmeras revoltas e motins locais que deixavam as suas cicatrizes impressas no número de feridos e mortos dispersos por toda a província. Logo, "não houve outro período mais violento, excetuando talvez os anos de guerra contra os holandeses" ${ }^{40}$. As tensões eclodiram já nas primeiras décadas do século XIX, quando o Recife foi palco de duas grandes "revoluções libertárias" (a Insurreição Pernambucana de 1817 e a Confederação do Equador em 1824), "todas sufocadas a ferro e a fogo" o que causava a impressão de uma aparente "tranquilidade" 41 . Para a viajante inglesa Maria Graham, que morou no Recife no período "entre revoluções" (em 1821), ou melhor, no momento em que se formava a Junta de Goiana, a cidade do Recife parecia estar sitiada - com poucos ou quase nenhum transeunte em seu traçado ${ }^{42}$.

Apesar da ameaça representada pelos "tempos revolucionários", era indispensável dar continuidade às atividades rotineiras que davam vida à capital da província e ofereciam sustento para muitos indivíduos. Após os intensos confrontos, a província parecia gozar de relativo sossego. Porém, a aparente "serenidade" duraria pouco, pois, chegada a década de 1830, tanto Pernambuco quanto outras províncias passaram por novos levantes e motins. Os reforços não eram suficientes para conter futuros levantes que se sucederam nos espaços da cidade, gerando um grande mal-estar social causado pelo sentimento de medo que assolava uma considerável parcela da população.

Assim revoltosos armados - com os mais variados instrumentos, tais como baionetas, facas, punhais, pedras e pedaços de madeira - tomaram as ruas e espaços da cidade, mobilizados em movimentos que ficaram conhecidos por "setembrada", "novembrada", 
"abrilada" e as "carneiradas". Alguns destes foram motivados por um forte sentimento antilusitano, pois muitos membros da população citadina, sobretudo, os mais pobres, acreditavam que o excesso de jovens portugueses, ocupando diversos cargos no comércio, proporcionava o aumento do desemprego que atingia, em particular, aos nascidos em terras brasileiras. Logo, sem emprego ou ocupação regular, a situação se tornaria mais periclitante para estes segmentos sociais e a fome, por tabela, se tornaria a maior companheira dos tempos difíceis.

Isto nos mostra que os populares também se rebelavam, ou seja, fugiam ao modelo de submissão e obediência. Mas, claro que as suas ações não ficavam de todo impunes perante às municipalidades que se utilizavam dos mais variados recursos (posturas e aparatos policiais) para tentar enquadrá-los nos padrões de ordem e obediência. Ainda assim, as autoridades citadinas contavam com uma forte resistência das chamadas "classes perigosas"

A "situação política da capital pernambucana parecia até fogo de monturo, ou seja, bastava uma brisa para acender as fagulhas dormidas e iniciar um novo incêndio" "44 . Porém, além da turba e violência, os "tempos de incertezas" ainda propiciavam a ampliação de problemas já considerados crônicos na cidade. Neste caso em particular, referimo-nos à questão do abastecimento de gêneros de primeira necessidade. A carestia de gêneros essenciais ao consumo diário da população não era nenhuma novidade na província. Afinal de contas, era resultado de um longo processo histórico de ocupação e exploração do seu solo.

A precariedade do setor de subsistência já era, em fins do século XVIII, objeto de preocupação para as autoridades. Segundo o governador da época, José de Melo, o problema seria a progressiva substituição das áreas de cultivo da mandioca pelo de algodão (produto que proporcionava bons lucros no mercado externo) e que, juntamente com a cana-de-açúcar, ocupavam um vasto território. Por esta razão, procurava incentivar o aumento da produção interna de mandioca, pois a partir de sua raiz se fabricava a farinha, "pão do indigente e miserável povo pernambucano" 45 . Para Tollenare, que esteve em Recife nos idos da primeira metade do século XIX, "a mandioca representava a base da alimentação de 7/8 dos habitantes da capitania de Pernambuco" ${ }^{\prime 46}$. Vale ressaltar que este gênero também era produzido em sítios presentes na paisagem do Recife - comumente descritos nos relatos destes viajantes. Isto se tratava de uma "solução doméstica ao problema do abastecimento interno"47.

Todavia, na maior parte do tempo, a produção não conseguia suprir a grande demanda e, por esta razão, a importação parecia ser uma solução. Conforme Caio Prado Jr., "Pernambuco, apesar de menos povoado que a Bahia dependeu muito mais que esta do 
abastecimento exterior, e na exportação de gêneros do Rio de Janeiro, figurou com volume cerca de duas vezes maior" ${ }^{\prime 4}$. Esta necessidade de importação de determinados gêneros, juntamente como outros fatores, já apontados, desencadeavam o constante aumento nos preços. Para Silvio Zancheti, “a hegemonia da cana era tão forte que mesmo produtos básicos para o sustento das áreas urbanas deviam ser importados de outras regiões brasileiras ou do exterior, tais como, os produtos frescos que se tornavam comumente caros em Recife"49. Outrofato corriqueiro praticado na época, segundo Gilberto Freyre era a falsificação de bebidas, em geral alcoólicas, e de alimentos. Esta prática "era geral. Falsificação, por um lado; escassez por outro". A adulteração foi uma tática utilizada por muitos para lucrar com os tempos de crise ${ }^{50}$.

Outro fator, não menos relevante, para o crescente aumento no preço dos produtos de primeira necessidade, "segundo os oficiais municipais da vila do Recife, se originava na atividade ilícita dos atravessadores". Esta preocupação era refletida nas trocas de cartas entre os membros da Câmara e o governador com intuito de solucionar o caso. O esquema de "travessia" se organizava da seguinte maneira: "um indivíduo abastado açambarcava os gêneros disponíveis a baixos preços e os repassava com preços altos" ${ }^{\text {" }}$, logo prejudicando parte da população que sem recursos financeiros não conseguia obter o necessário à sua subsistência. Além disso, para as repartições públicas, tal prática conduziria a uma constante redução na arrecadação de impostos (em particular, sobre a carne verde e a cachaça) e, nesse caminho, por comprometer a sua receita se dificultaria o pagamento das tropas, tendo em vista que estes já recebiam uma pequena quantia de emolumentos em troca de seus serviços e atribuições.

Então, quais seriam os gêneros em questão? Sobretudo, os vitais como a carne verde, a farinha de mandioca e de trigo, entre outros produtos que eram tidos como base alimentar da população. E que, com frequência, faltavam nas vendas e nos mercados da cidade. Na passagem para o século XIX, as condições de consumo se tornavam mais críticas principalmente para a população mais pobre, em virtude das fortes secas que agravavam seriamente a produção de alimentos, pois causavam inúmeros prejuízos a lavoura e a criação de animais. Isso promovia o constante aumento no preço dos víveres de primeira necessidade em detrimento da copiosa demanda.

A situação parecia fugir ao controle das autoridades e da própria população. As razões eram muitas e os seus efeitos eram temidos; a preocupação das autoridades não era sem propósito, pois a população também lhes cobrava providências. Isso foi exposto em um ofício 
datado de 10 de junho de 1824, pelo escrivão José Joaquim de Oliveira Maciel, funcionário da Câmara Municipal da cidade do Recife, que diz:

[...] nesta Cidade do Recife [...] dela onde se achavão o Juiz de Fora pela lei, vereadores, e Procurador [...] que forão congregados por requerimento de pessoas do Povo para representarem a necessidade de providências sobre a falta de víveres da primeira necessidade sobre o qual se tomarão as medidas concernentes oficiando ao Excelentíssimo Presidente da Província $[\ldots]^{52}$.

Entre os segmentos populares (os mais vitimados por estas circunstâncias) havia indivíduos que se valiam das instâncias públicas para defenderem os seus interesses e assim procuravam atender as suas necessidades. Portanto, não se silenciavam diante das adversidades acometidas pelas precárias condições de consumo na província. Não era recorrente este tipo de reivindicação tomando como interlocutor o próprio Estado, mas os seus indícios nos mostram as possíveis "brechas" conquistadas e possibilitadas a "gente comum", nem sempre levados em consideração e pouco tolerados por certos "homens da governança".

Já em meados de 1831, mais uma vez, a Câmara Municipal colocou esse problema em pauta. Com o intento de conter e corrigir os "maus costumes" dos atravessadores usualmente apontados pelas autoridades locais como um dos principais responsáveis pela fome na cidade - fez publicar algumas posturas sobre o assunto. Logo, em artigo $9^{\circ}$ presente no Título $13^{\circ}$ (Sobre a polícia dos mercados, portos de embarque, pescarias, padarias) determinou que "qualquer atravessador, que for encontrado com qualquer gênero de farinha, legumes, e peixes" destinados apenas a "venda Pública nas Praças, ou Ribeiras, e pelas ruas (em ocasião de abundância) pelos seus próprios donos, ou condutores" seriam, por isso, "condenados com a pena de oito dias de Cadeia"54.

Contudo, a obediência não foi regra e o descumprimento da dita postura levou alguns indivíduos para trás das grades. Assim, em 17 de fevereiro de 1838, seguiram esse destino o “João Jacinto Soares (branco)" e "Joaquim de tal (pardo)", ambos remetidos à prisão "por serem atravessadores de farinhas", portanto "contra as ordens a respeito" em Santo Antônio, foi preso "Jozé Joaquim (branco)" pela mesma infração, ou seja, "por ser atravessador de gêneros de primeira necessidade em detrimento das pessoas indigentes" Não sabemos se os contraventores chegaram sequer a cumprir os oitos dias de prisão conforme os ditames da dita lei municipal, mas podemos inferir que o cotidiano desses e de outros sujeitos tidos como infratores não se reduziam facilmente às determinações das leis. Do mesmo modo, a punição pelo crime de "contrabando" ou desvio irregular de alimentos estava longe de resolver o problema da fome que imperava na cidade. 
No ano de 1845, foi publicado no Diário de Pernambuco um quadro cronológico enumerando os principais males que afetaram, sobremaneira, o desenvolvimento do progresso da província de Pernambuco. Neste quadro, faz-se referência à presença marcante da fome e das epidemias, logo:

[...] Em $1^{\circ}$ a porfiada e longa guerra contra os holandeses [...]; em $2^{\circ}$, a peste de bexigas, que grassou em meados de 1664 até 1666 [...], cujos estragos deveriam ser espantosos [...]; $3^{\circ}$ a peste ou moléstia denominada de Males segundo uns, e segundo outros, Bicho, $[\ldots]$ que ceifou para mais de duas mil pessoas; $4^{\circ}$ a epidemia de febres, que principiou no tempo de governador, o Marquês de Monte Belo, de 1690 a 1696, proveniente de um barril de carne podre, que se abriu na Rua da Praia; $5^{\circ}$ a sedição de 1710 a 1711 por ocasião da criação da Vila do Recife, [...] morreram por amor dela 600 habitantes; $6^{\circ}$ as fomes, mortes e misérias acontecidas no tempo do Governador Manuel Rolim de Moura desde 1722 a 1727, emconsequência do que se deram diferentes providências sobre os enterros nas igrejas e se mandou construir um cemitério público; em $7^{\circ}$ a epidemia das bexigas, que grassou com violência

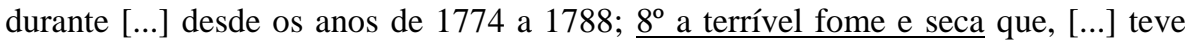
lugar por três anos sucessivos desde 1791 a 1793, cujos estragos ceifaram uma terça parte da população [...]; e $\underline{9^{\circ} \text {, finalmente, as emigrações provenientes das revoluções }}$ de 1817 e seguintes, as desgraças que elas ocasionaram, e os poucos ou nenhuns meios empregados para conservar a saúde pública, preservá-la de moléstias. ${ }^{57}$ Grifos nossos.

No documento, a fome é citada duas vezes, ocupando a sexta e a oitava posição no dado "ranking de males" apontados em 1845. As suas circunstâncias se agravavam em tempos de revoltas; de secas; de enchentes e de epidemias que cobriam a população com vestes de terror e de morte. É importante ressaltar que o periódico só trata dos problemas até o ano de 1817, curioso não? Pois, após esta data muitos outros problemas se sucederam tanto na província quanto em sua capital; como já tratamos, as agitações sociais não haviam cessado.

Outro ponto relevante abordado foi o da saúde pública. As epidemias e moléstias foram apontadas cinco vezes superando até mesmo o flagelo da fome; a situação era alarmante. A questão da salubridade se tornou uma das prioridades de atuação do Estado a fim de melhor conduzir e controlar os hábitos pouco higiênicos da população. Mas, ainda assim, as tentativas de controle desta instituição não conseguiram impedir os efeitos nefastos dos surtos epidêmicos, em particular, da cólera morbus e varíola. Todavia, as epidemias que assolavam Pernambuco e as demais províncias na época, encontravam ambiente propício à sua propagação, dada as precárias condições sanitárias e os hábitos pouco salubres da população. O discurso do jornal traz sinais de uma época seduzida pelo "progresso" e que, por este motivo, pretende-se exibir na condição de bela, segura e sã.

Na tentativa de acobertar a cidade dos possíveis riscos de surtos febris, de cólera e de varíola, a vacinação seria adotada como um dos meios para assegurar a salubridade perante a 
sociedade. Embora, não tivesse sido possível atender à demanda populacional tendo em vista as inúmeras deficiências das repartições responsáveis pela administração da saúde pública em Pernambuco. Ademais entre os populares incidia uma forte resistência para com o emprego das práticas médicas. Nos idos de 1839, o presidente da província Rego Barros expressou diante da Assembleia Legislativa os empecilhos que dificultavam sobremaneira o bom funcionamento da saúde pública visto,

[...] o Governo e mais authoridades d'ella carecem dos meios necessários para promover a salubridade publica, pela falta de pessoas, a quem possa consultar sobre os diversos ramos da Hygiene Publica. Seria pois conveniente, que estabelecesseis um Conselho de Salubridade entre nósá semelhança do que se tem praticado em diversos paizes da Europa, e acaba de sel-o ultimamente na Provincia da Bahia $[\ldots]^{58}$.

Contudo, foi só a partir do ano de 1845 que Pernambuco passou finalmente a contar com o auxílio do Conselho de Salubridade Pública para fazer "inspecionar, vigorar e prover sobre todos os assuntos que se referissem à Higiene Pública e a Polícia Sanitária" ${ }^{, 59}$. Quanto ao problema da falta de pessoas aptas para os serviços nos "ramos da Higiene" ainda continuava a ser um grande entrave, difícil de ser solucionado. Nesse âmbito, as queixas circulavam com certa frequência e eram registradas em ofícios diversos (elaborados pela referida instituição, pela Câmara Municipal e pela Assembleia Legislativa); não só isso, os impressos da época também se reportavam a este respeito e procuravam denunciar tais carências.

Nestas circunstâncias, a economia local já estava para lá de abalada. Pois, enfrentava um grande déficit e o constante crescimento da inflação que propiciava ainda mais o encarecimento do custo de vida, o que afetava principalmente os segmentos populares. Haja vista a cobrança de diversos tributos e impostos que, segundo o inglês Henry Koster, "pela maneira com que foram estabelecidos, pesam mais sobre as classes baixas e não alcançam a quem os poderia suportar desafogadamente" ${ }^{\natural 0}$. A situação parecia se agravar em virtude do grande fluxo de "moedas falsas" no mercado citadino. A sua circulação gerou uma enorme confusão. Com receio de terem prejuízos, pequenos comerciantes, vendeiras, taberneiros, aguadeiros, entre outros que viviam do comércio a retalho se recusavam a receber pagamentos feitos com estas moedas. A situação se agravava no dia-a-dia, em decorrência de boa parte destes segmentos não conseguirem distinguir as diferenças entre a moeda de cobre e a moeda falsificada. 
Os fatos ganharam repercussão, assim como a preocupação das autoridades imperiais, que anunciavam através de ofícios diversos e em periódicos, as consequências destinadas àqueles que pretendessem "rejeitar caprichosamente a moeda de cobre em giro, a pretexto de falsa". Por ocasião de se acharem as "pessoas indigentes privadas dos gêneros de primeira necessidade da vida", tal circunstância foi tida como "injusta". Para isso, tomaram-se providências e se empregou forças policiais para se prevenir qualquer burburinho que possa ser deflagrado pelas ruas da capital ${ }^{61}$. Ora, era justamente este dinheiro que circulava pelas mãos das classes menos favorecidas.

Portanto, viver e permanecer na cidade do Recife ou até mesmo em seus arrabaldes, não deveria ser tarefa fácil haja vista o elevado custo de vida, as turbulências em suas ruas, os problemas oriundos das cheias e secas, entre outros fatores que comprometiam, sobremaneira, ao atendimento de necessidades tidas como mínimas e essenciais à sobrevivência, tais como: a alimentação, a habitação, o vestuário, a mobilidade. No entanto, apesar de todas estas circunstâncias, a cidade continuava sob o seu manto de poder e de majestade. E, assim uma boa parcela da população continuava a crer que talvez em seus limites poderia viver dias melhores. O ideário de "progresso" parecia suprimir e, ao mesmo passo, conduzir o "espetáculo da pobreza" que se apresentava à cidade. Mesmo com turbulências de toda ordem, a cidade continuava a concentrar bens, serviços e uma grande população que se "espremia" em seus limites. A vigilância das autoridades municipais preocupadas em garantir o "bem público", apesar de constante, não parecia dar conta das "peripécias” da gente comum.

\section{Notas}

\footnotetext{
${ }^{1}$ ARRAIS, Raimundo. O Pântano e o Riacho: A formação do espaço público no Recife do século XIX. São Paulo: Humanitas/FFLCH/USP, 2004, p. 101.

${ }^{2}$ Tomamos este termo emprestado do historiador Sérgio Buarque de Holanda que o utiliza para fazer referência às principais cidades brasileiras da época, ao passo em que todas também eram as capitais das suas respectivas províncias. Nesse caso, seriam estas: o Rio de Janeiro, Salvador e Recife. Ver HOLANDA, Sérgio Buarque de. Raízes do Brasil. 26 ed. São Paulo: Companhia das Letras, 1995, p. 41-70.

${ }^{3}$ ARRAIS, 2004, p. 113.

${ }^{4}$ Os limites geográficos e as jurisdições dos bairros centrais do Recife, assim como, de seus arrabaldes sofreram inúmeras alterações espaciais ao longo dos oitocentos; tais fatores, em muito contribuíram para gerar confusões e atritos. As configurações em unidades políticas e judiciais não se deviam apenas às imposições do meio natural, mas também era fruto de questões políticas - os territórios eram divididos de acordo os interesses partidários daqueles que estavam à frente do poder. Portanto, ainda em meados da década de 1840 estes limites não constavam como definidos pelas autoridades representantes da Câmara Municipal do Recife.

${ }^{5}$ MATTOSO apud SILVA, Maciel Henrique Carneiro da. Pretas de honra: trabalho, cotidiano e representações de vendeiras e criadas no Recife do século XIX (1840-1870). Recife: Dissertação (Mestrado em História) Universidade Federal de Pernambuco, Recife, 2004, p. 26.
} 
${ }^{6}$ FREYRE apudCARVALHO, Marcus Joaquim Maciel de. Liberdade: rotinas e rupturas do escravismo no Recife, 1822-1850. Recife: Editora Universitária da UFPE, 1998, p. 22.

${ }^{7}$ CARVALHO, Marcus Joaquim M. de. De Portas Adentro e de Portas Afora: Trabalho doméstico e escravidão no Recife, 1822-1850. In: Afro-Ásia, Salvador, n. 29/30, 2003, p. 58.

${ }^{8}$ BARREIRO, José Carlos. Imaginário e viajantes no Brasil do século XIX: cultura e cotidiano, tradição e resistência. São Paulo: UNESP, 2002, p. 68-69.

${ }^{9}$ PECHMAN, Robert Moses. Cidades Estreitamente Vigiadas: o detetive e o urbanista. Rio de Janeiro: Casa da Palavra, 2002, p. 17.

${ }^{10}$ Segundo Estevão Pinto, "as rótulas consistiam em grades [...], cordões ou tiras paralelas de madeira, cruzadas em aspas ou formando espinhas, aplicadas às janelas, portas, sacadas e varandas em geral". O seu uso era corrente apenas em "casas pobres" que passaram a sofrer forte vigilância, em virtude de denúncias de se utilizarem urupemas também em casas tidas como "suspeitas" - sobretudo, casas associadas à prática do baixo meretrício. PINTO, Estevão apud AQUINO, Aécio Villar de. Nordeste século XIX. João Pessoa: Editora Universitária UFPB, 1980, p. 57-58.

${ }^{11} \mathrm{O}$ viajante inglês deu esta opinião, ao perceber as transformações ocorridas na cidade do Recife num intervalo de sete anos, após a data da sua primeira estada na província (1809). KOSTER, Henry. Viagens ao Nordeste do Brasil 1793-1820. 11. ed. atual. Recife: Fundação Joaquim Nabuco, Editora Massangana, 2002, p. 335.

${ }^{12}$ COSTA, Francisco Augusto Pereira da. Anais Pernambucanos. Recife: FUNDARPE, 1984, vol. 09 (1824 1833), p. 353.

${ }^{13}$ KOSTER, 2002, p. 336.

${ }_{15}^{14}$ Ibid., p. 71.

${ }^{15}$ PARAHYM, Orlando. Traços do Recife: ontem e hoje. Recife: Secretaria de Educação e Cultura, 1978, p. 49.

${ }^{16}$ BARROS, Francisco do Rego. Falla na ocasião da abertura da Assembléia Legislativa Provincial de Pernambuco. Recife: 01 de março de 1838, p. 01. Disponível em: http://brazil.crl.edu/bsd/bsd/u2361/000003.html

${ }^{17}$ SILVA FILHO, Paulo Alexandre. Desvalorização do Trabalho e Consumo Honorífico em Recife (18371844). Dissertação (Mestrado em História) - Universidade Federal de Pernambuco, Recife, 2007, p. 68-69.

${ }^{18}$ Tomamos o termo "cidade negra" emprestado, por designar as sociedades escravistas da época, aos quais os africanos e afro-descendentes compunham a maior parte da população. Cf. ARAÚJO, Carlos Eduardo Moreira de (Coord.). Cidades Negras: Africanos, crioulos e espaços urbanos no Brasil escravista do século XIX. 2. ed. São Paulo: Alameda, 2006.

${ }^{19}$ A afirmação de João José Reis se refere à cidade de Salvador na Bahia, no período em foco. Realidade não tão distante da existente em Recife e, até mesmo, nas demais capitais brasileiras da época. REIS, João José. Rebelião escrava no Brasil: a história do levante dos malês em 1835. São Paulo: Companhia das Letras, 2003, p. 30

${ }^{20}$ VILHENA apud PECHMAN, 2002, p. 24.

${ }^{21}$ MELLO e SOUZA, Laura de. Desclassificados do ouro: a pobreza mineira no século XVIII. 4. ed. Rio de Janeiro: Graal, 2004, p. 90.

${ }^{22}$ LAPA, José Roberto do Amaral. Os Excluídos: contribuição à história da pobreza no Brasil (1850-1930). Campinas, São Paulo: Editora da Unicamp/EDUSP, 2008, p. 36.

${ }^{23}$ Vale pontuar que a questão da saúde pública configurava como um dos pilares a serem desenvolvidos pelo Estado Imperial e que deveria estar em consonância com os conceitos de estética, justiça, cultura, moral e segurança, tudo em prol da "civilização". GONDRA, José. Artes de Civilizar: medicina, higiene e educação escolar na Corte Imperial. Rio de Janeiro: Ed. UERJ, 2004, p. 94.

${ }^{24}$ Idem, p. 40-41.

${ }^{25}$ GONDRA, 2004, p. 87-88.

${ }^{26}$ VILLERMÉ apud PINTO, Sérgio Maurício Costa da Silva. Família de Negros: entre a pobreza e a herança cultural. Rio de Janeiro: FAPERJ, E-papers, 2009, p. 64.

${ }^{27}$ LAPA, 2008, p. 28-29.

${ }^{28}$ SILVA, Antonio de Morais. Diccionario da LinguaPortugueza. vol. 2, p. 460. Material disponível em http://brasiliana.usp.br/dicionario/2/pobre

${ }^{29}$ FONSECA, J. da. Diccionario da língua Portugueza. Pariz: Livreiro de Sua Magestade o Imperador do Brasil e El-Rei de Portugal, 1878, p. 763.

${ }^{30}$ Ao analisar o caráter insurreto das camadas populares na cidade, que tratou por "pobres urbanos", Marco Pamplona fez relação à composição complexa desse segmento social, por sinal, "de classificação nada fácil". Por esta razão, vale salientar que encontramos algumas dificuldades para categorizar tanto o termo "pobre" quanto "pobreza". Pois, carregam consigo uma historicidade que precisa ser levada em consideração e relativizada, para não cometermos generalizações precipitadas acerca dos mesmos. PAMPLONA, Marco A. A historiografia sobre 
o protesto popular: uma contribuição para o estudo das revoltas urbanas. Rio de Janeiro: Revista de Estudos Históricos, 1996, n ${ }^{\circ} .17$, p. 225.

${ }^{31}$ REIS, 2003, p. 20- 32.

${ }^{32}$ TOLLENARE, Louis François de. Notas Dominicais. Recife: Secretaria de Educação e Cultura de Pernambuco, 1978, p. 40.

${ }^{33}$ CASTRO, Hebe Maria Mattos de. Ao sul da história: lavradores pobres na crise do trabalho escravo. 2. ed. Rio de Janeiro: Ed. FGV, FAPERJ, 2009, p. 72-73.

${ }^{34}$ SILVA, Leonardo Dantas (Org.). O Carapuceiro: o padre Lopes Gama e o Diário de Pernambuco 1840-1845. Recife: FUNDAJ/Ed. Massangana, 1996, p. 27.

${ }^{35}$ PAMPLONA apud CÂMARA, Bruno Augusto Dornelas. Trabalho livre no Brasil Imperial: o caso dos caixeiros de comércio na época da Insurreição Praieira. Dissertação (Mestrado em História) - Universidade Federal de Pernambuco, Recife, 2005, p. 28.

${ }^{36}$ GAMA, Miguel do Sacramento Lopes. O Carapuceiro, 19 de junho de 1837, p. 04. Recife: Fundação de Cultura Cidade do Recife, 1983, vol. II.

${ }^{37}$ ZANCHETI, Silvio Mendes. O Estado e a cidade do Recife (1836-1889). São Paulo: Tese de doutoramento apresentada à Faculdade de Arquitetura e Urbanismo da USP, 1989, p. 85.

${ }^{38}$ CAVALCANTI JUNIOR, Manoel Nunes. "Praieiros", "guabirus" e "populaça": as eleições gerais de 1844 no Recife. Dissertação (Mestrado em História) - Universidade Federal de Pernambuco, Recife, 2001, p. 23-24.

${ }^{39}$ CÂMARA, 2005, p. 95-96.

${ }^{40}$ CARVALHO, 1998, p. 05.

${ }^{41}$ SILVA, Wellington Barbosa da. Entre a liturgia e o salário: a formação dos aparatos policiais no Recife do século XIX. Tese (Doutorado em História) - Universidade Federal de Pernambuco, Recife, 2003, p. 16-18.

${ }^{42}$ GRAHAM, Maria. Diário de uma Viagem ao Brasil. Belo Horizonte: Itatiaia, 1990, v.1, p. 141-142.

${ }^{43}$ O termo "perigoso" era atribuído pelas autoridades e pela imprensa da época aos segmentos populares, sobretudo aos vadios, aos mendigos e aos infratores. "Qualificavam-nos" a fim de responsabilizá-los pelo "caos" que se encontrava a cidade e proporcionar uma maior vigilância sobre esses sujeitos. Da mesma forma, eles seriam tratados de maneira a distinguir o sujeito "perigoso", do sujeito "pacato" que estaria longe de representar os populares.

${ }^{44}$ SILVA, 2003, p. 19.

${ }^{45}$ MELlO, José Antonio Gonsalves de. O Diário de Pernambuco e a História Social do Nordeste (18401889). Recife: Edição Comemorativa do Sesquicentenário do Diário de Pernambuco, 1975, v. II,p. 64.

${ }^{46}$ TOLLENARE, 1978, p. 38.

${ }^{47}$ FREYRE, Gilberto. Sobrados e Mucambos: decadência do patriarcado rural e desenvolvimento urbano. 10. ed. Rio de Janeiro: Record, 1998, p. 165.

${ }^{48}$ PRADO JÚNIOR, apud LEITE, Glacyra Lazzari. Pernambuco 1817: Estrutura e comportamentos sociais. Recife: FUNDAJ, Ed. Massangana, 1988, p.64.

${ }^{49}$ ZANCHETI, 1989, p. 76.

${ }^{50}$ FREYRE, 1998, p. 165.

${ }^{51}$ SOUZA, George Felix Cabral de. Os homens e os modos de governança: a Câmara Municipal do Recife no século XVIII. Recife: Gráfica Flamar, 2003, p. 128-129.

${ }^{52}$ Ofício de Termo de Vereação Extravagante de 10 de junho de 1824, Livro no ${ }^{\circ} 4$ de Vereações e Acordos da Câmara Municipal do Recife, f. 146, IAHGP.

53 THOMPSON, Edward Palmer. Senhores e caçadores: a origem da lei negra. Rio de Janeiro: Paz e Terra, 1987, p. 57.

${ }^{54}$ Diário de Pernambuco, 23 de dezembro de 1831, no 272, p. 1101-1102.

55 APEJE - Arquivo Público Estadual Jordão Emereciano, Prefeitura de Comarca do Recife, cód. 07, fl. 84. Ofício do Prefeito de Comarca do Recife, Francisco Antônio de Sá Barreto, ao Presidente da Província, de 17/02/1838.

${ }^{56}$ APEJE - Arquivo Público Estadual Jordão Emereciano, Prefeitura de Comarca do Recife, cód. 10, fl. 69. Ofício do Prefeito de Comarca do Recife, Francisco Antônio de Sá Barreto, ao Presidente da Província, de 07/08/1839.

${ }^{57}$ MELlO, José Antonio Gonsalves de. O Diário de Pernambuco e a História Social do Nordeste (18401889). Recife: Edição Comemorativa do Sesquicentenário do Diário de Pernambuco, 1975, v. II,p. 435-436.

${ }^{58}$ BARROS, Francisco do Rego. Relatório que para Assembleia Legislativa de Pernambuco apresentou na Sessão Ordinária. Recife: 1839, p. 24. Disponível em: http://brazil.crl.edu/bsd/bsd/

${ }^{59}$ COSTA, Veloso. Alguns aspectos históricos e médicos do Recife. Recife: Editora da Universidade Federal de Pernambuco, 1971, p. 99. 
${ }^{60}$ KOSTER, Henry. Viagens ao Nordeste do Brasil 1793-1820. 11. ed. atual. Recife: Fundação Joaquim Nabuco, Editora Massangana, 2002, p. 106.

${ }^{61}$ Diário da Administração Pública de Pernambuco, Recife, 10 de Janeiro de 1834, tomo II, n. 07, p. 01.

\section{Referências Bibliográficas}

AQUINO, Aécio Villar de. Nordeste século XIX. João Pessoa: Editora Universitária UFPB, 1980.

ARRAIS, Raimundo. O Pântano e o Riacho: A formação do espaço público no Recife do século XIX. São Paulo: Humanitas/FFLCH/USP, 2004.

BARREIRO, José Carlos. Imaginário e viajantes no Brasil do século XIX: cultura e cotidiano, tradição e resistência. São Paulo: UNESP, 2002.

CÂMARA, Bruno Augusto Dornelas. Trabalho livre no Brasil Imperial: o caso dos caixeiros de comércio na época da Insurreição Praieira. Dissertação (Mestrado em História) Universidade Federal de Pernambuco, Recife, 2005.

CARVALHO, Marcus Joaquim Maciel de. Liberdade: rotinas e rupturas do escravismo no Recife, 1822-1850. Recife: Editora Universitária da UFPE, 1998.

Marcus Joaquim M. de. De Portas Adentro e de Portas Afora: Trabalho doméstico e escravidão no Recife, 1822-1850. In: Afro-Ásia, Salvador, n. 29/30, 2003.

CASTRO, Hebe Maria Mattos de. Ao sul da história: lavradores pobres na crise do trabalho escravo. 2. ed. Rio de Janeiro: Ed. FGV, FAPERJ, 2009.

CAVALCANTI JUNIOR, Manoel Nunes. "Praieiros", "guabirus" e "populaça": as eleições gerais de 1844 no Recife. Dissertação (Mestrado em História) - Universidade Federal de Pernambuco, Recife, 2001.

COSTA, Francisco Augusto Pereira da. Anais Pernambucanos. Recife: FUNDARPE, 1984, vol. 09 (1824 - 1833).

COSTA, Veloso. Alguns aspectos históricos e médicos do Recife. Recife: Editora da Universidade Federal de Pernambuco, 1971.

FREYRE, Gilberto. Sobrados e Mucambos: decadência do patriarcado rural e desenvolvimento urbano. 10. ed. Rio de Janeiro: Record, 1998.

GAMA, Miguel do Sacramento Lopes. O Carapuceiro, 19 de junho de 1837, p. 04. Recife: Fundação de Cultura Cidade do Recife, 1983, vol. II.

GONDRA, José. Artes de Civilizar: medicina, higiene e educação escolar na Corte Imperial. Rio de Janeiro: Ed. UERJ, 2004.

GRAHAM, Maria. Diário de uma Viagem ao Brasil. Belo Horizonte: Itatiaia, 1990.

HOLANDA, Sérgio Buarque de. Raízes do Brasil. 26 ed. São Paulo: Cia das Letras, 1995.

KOSTER, Henry. Viagens ao Nordeste do Brasil 1793-1820. 11. ed. atual. Recife: Fundação Joaquim Nabuco, Editora Massangana, 2002.

LAPA, José Roberto do Amaral. Os Excluídos: contribuição à história da pobreza no Brasil (1850-1930). Campinas, São Paulo: Editora da Unicamp/EDUSP, 2008. 
LEITE, Glacyra Lazzari. Pernambuco 1817: Estrutura e comportamentos sociais. Recife: FUNDAJ, Ed. Massangana, 1988.

MELlO, José Antonio Gonsalves de. O Diário de Pernambuco e a História Social do Nordeste (1840-1889). Recife: Edição Comemorativa do Sesquicentenário do Diário de Pernambuco, 1975, v. II.

MELLO e SOUZA, Laura de. Desclassificados do ouro: a pobreza mineira no século XVIII. 4. ed. Rio de Janeiro: Graal, 2004.

PAMPLONA, Marco A. A historiografia sobre o protesto popular: uma contribuição para o estudo das revoltas urbanas. Rio de Janeiro: Revista de Estudos Históricos, 1996, nº 17.

PARAHYM, Orlando. Traços do Recife: ontem e hoje. Recife: Secretaria de Educação e Cultura, 1978.

PECHMAN, Robert Moses. Cidades Estreitamente Vigiadas: o detetive e o urbanista. Rio de Janeiro: Casa da Palavra, 2002.

PINTO, Sérgio Maurício Costa da Silva. Família de Negros: entre a pobreza e a herança cultural. Rio de Janeiro: FAPERJ, E-papers, 2009.

REIS, João José. Rebelião escrava no Brasil: a história do levante dos malês em 1835. São Paulo: Companhia das Letras, 2003.

SILVA, Leonardo Dantas (Org.). O Carapuceiro: o padre Lopes Gama e o Diário de Pernambuco 1840-1845. Recife: FUNDAJ/Ed. Massangana, 1996.

SILVA, Maciel Henrique Carneiro da. Pretas de honra: trabalho, cotidiano e representações de vendeiras e criadas no Recife do século XIX (1840-1870). Recife: Dissertação (Mestrado em História) - Universidade Federal de Pernambuco, Recife, 2004.

SILVA, Wellington Barbosa da. Entre a liturgia e o salário: a formação dos aparatos policiais no Recife do século XIX. Tese (Doutorado em História) - Universidade Federal de Pernambuco, Recife, 2003.

SILVA FILHO, Paulo Alexandre. Desvalorização do Trabalho e Consumo Honorífico em Recife (1837-1844). Dissertação (Mestrado em História) - Universidade Federal de Pernambuco, Recife, 2007.

SOUZA, George Felix Cabral de. Os homens e os modos de governança: a Câmara Municipal do Recife no século XVIII. Recife: Gráfica Flamar, 2003.

THOMPSON, Edward Palmer. Senhores e caçadores: a origem da lei negra. Rio de Janeiro: Paz e Terra, 1987.

TOLLENARE, Louis François de. Notas Dominicais. Recife: Secretaria de Educação e Cultura de Pernambuco, 1978.

ZANCHETI, Silvio Mendes. O Estado e a cidade do Recife (1836-1889). São Paulo: Tese de doutoramento apresentada à Faculdade de Arquitetura e Urbanismo da USP, 1989. 